\title{
PENGARUH VARIASI BAHAN PEREKAT TERHADAP LAJU PEMBAKARAN BIOBRIKET CAMPURAN BATUBARA DAN SABUT KELAPA
}

\author{
Amin Sulistyanto \\ Jurusan Teknik Mesin Fakultas Teknik \\ Universitas Muhammadiyah Surakarta \\ Jl. A. Yani Tromol Pos I Pabelan Surakarta \\ E-mail:amin_sulistyanto@ums.ac.id
}

\begin{abstract}
ABSTRAK
Kekhawatiran akan semakin menipisnya dan mahalnya Bahan Bakar Minyak (BBM) semakin terasa dalam beberapa tahun terakhir sehingga timbul pemikiran untuk mengolah biomas yang kurang termanfaatkan menjadi bahan bakar alternatif. Sabut kelapa belum termanfaatkan sepenuhnya, padahal sabut kelapa merupakan biomas dengan kandungan energi yang relatif besar. Apabila sabut kelapa tersebut diolah bersama-sama dengan batu bara, bahan perekat dan zat pengikat polutan akan menjadi satu bahan bakar padat buatan sebagai bahan bakar alternatif.

Dalam penelitian ini, yang akan diteliti adalah karakteristik pembakaran biobriket campuran sabut kelapa dan batubara lignite (70\% : 30\%), dengan bahan perekat pati kanji dan tetes tebu yang komposisinya masing-masing 1 gram, 2 gram dan 3 gram. Biobriket yang diteliti mendapatkan perlakuan yang sama, yaitu tekanan pengepresan $100 \mathrm{~kg} / \mathrm{cm}^{2}$, berat biobriket $4 \mathrm{~g}$ dan pada saat proses pembakaran kecepatan udara dibuat $0,3 \mathrm{~m} / \mathrm{s}$, temperatur dinding $100^{\circ} \mathrm{C}-120^{\circ} \mathrm{C}$, temperatur preheater $52^{\circ} \mathrm{C}-56^{\circ} \mathrm{C}$ serta temperatur udara $34^{\circ} \mathrm{C}-38^{\circ} \mathrm{C}$.

Dari penelitian didapatkan bahwa karakteristik pembakaran biobriket yang baerbahan perekat pati memiliki temperatur pembakaran yang lebih tinggi dan tetes tebu menghasilkan polusi yang lebih tinggi.
\end{abstract}

Kata kunci : Biobriket, Sabut kelapa, Bahan perekat, Karakteristik pembakaran

\section{PENDAHULUAN}

Kekhawatiran akan semakin menipisnya sumber daya energi terutama bahan bakar fosil dan juga mahalnya Bahan Bakar Minyak semakin terasa dalam beberapa tahun terakhir sehingga dari kenyataan ini banyak hal yang dilakukan untuk mengatasi masalah tersebut, salah satu diantaranya adalah dengan mencari sumber energi alternatif.

Disisi lain, sabut kelapa merupakan biomas yang belum termanfaatkan secara menyeluruh. Padahal sabut kelapa merupakan energi alternatif yang memiliki kandungan energi yang relative besar, apabila sabut kelapa diolah bersama-sama dengan batu bara dan zat pengikat polutan akan menjadi satu bahan bakar padat buatan sebagai bahan bakar alternatif yang bernama biobriket.

Berbagai penelitian telah dilakukan untuk menganalisa karakteristik pembakaran pada Bio-Briket, yang mana dilakukan sebagai tolak ukur untuk pembuatan bahan bakar dari bahan 
yang mudah didapat dan efisien dalam penggunaannya.

\section{Batasan Masalah}

Untuk menghindari melebarnya masalah, maka perlu adanya pembatasan masalah sebagai berikut:

Dalam penelitian ini masalah yang diteliti karateristik pembakaran yang meliputi laju pembakaran, temperatur pembakaran dan polusi yang ditimbulkan dalam pembakaran biobriket sebagai akibat variasi bahan perekat.

\section{Tujuan Penelitian}

1. Mengetahui pengaruh bahan perekat terhadap laju pembakaran.

2. Mengetahui pengaruh bahan perekat terhadap temperatur pembakaran.

3. Mengetahui pengaruh bahan perekat terhadap polusi pembakaran.

4. Menentukan karakter pembakaran biobriket yang terbaik.

\section{TINJAUAN PUSTAKA}

Naruse et al (1999) melakukan penelitian mengenai karakteristik pembakaran biomass yang berasal dari limbah jagung. Didapatkan bahwa karakteristik pembakaran biomasa tergantung dari komposisi biomasa semisal lignin dan cellulose, disamping itu juga didapatkan bahwa biomass dapat memperbaiki proses penyalaan dan pembakaran batubara, selain itu dalam pembakaran antar batubara dan biomasa akan ditangkap oleh abu dari batubara selama proses pembakaran.

Beberapa masalah yang berhubungan dengan pembakaran limbah pertanian adalah kadar air, bulk density, kadar abu dan kadar volatile matter. Kadar air yang tinggi dapat menyulitkan penyalaan dan mengurangi temperatur pembakaran. Kadar volatile matter yang tinggi pada limbah pertanian mengindikasikan bahwa limbah pertanian mudah menyala dan terbakar, walaupun pembakaran lebih cepat dan sulit dikontrol.hal ini ditemui dalam penelitian pembakaran limbah pertanian yang dilakukan oleh Werther (2000) dalam (Himawanto, 2003).
Sudrajat (2000) melakukan penelitian tentang pemanfaatan energi dari biomasa sebagai sumber energi alternatif, dimana dia mendapatkan data yang menunjukkan besarnya tingkat sampah yang dihasilkan dibeberapa kota besar di Indonesia pada tahun 2000 yang mana sebagian besarnya adalah sampah organik yang mempunyai nilai kalor yang cukup tinggi.

Penelitian mengenai pembakaran antara jerami dan batubara diteliti oleh Pedersen et al, (1996) dalam (Himawanto, 2003) yang dalam risetnya menghasilkan kesimpulan bahwa dengan pembakaran antara jerami dan batubara Kanada, emisi $\mathrm{NO}$ dan $\mathrm{SO}_{2}$ dapat direduksi bila dibandingkan dengan pembakaran batubara saja, juga terjadi penurunan kadar asap dan abu.

Biobriket mempunyai temperatur penyalaan (ignition temperatur) yang lebih rendah dan burnout time yang lebih pendek dibandingkan dengan briket batubara. Ketika briket dipanasi, temperaturnya naik, setelah mencapai temperatur tertentu, volatile matter keluar dan terbakar disekitar briket. Temperatur nyala turun jika campuran biomasa lebih banyak volatile matter dan temperatur nyala biomasa lebih rendah dari batubara. Penambahan biomassa pada biobriket dapat meningkatkan kemampuan nyala briket (Naruse ,1998).

Hal-hal penting dalam pembakaran :

\section{Pembakaran bahan bakar padat}

Dalam pembakaran bahan bakar padat tahap pertama yang terjadi adalah pengeringan, yaitu suatu proses ketika suatu partikel dipanaskan dan dikenai temperature tinggi dan menyebabkan moisture di permukaan bahan bakar tersebut akan menguap. Kemudian dilanjutkan dengan proses devolatilisasi. Pada tahap ini bahan bakar mengalami dekomposisi termal, yaitu pecahnya ikatan kimia secara termal dan keluarnya volatile matter dari partikel. Laju devolatilisasi dan hasil devolatilisasi tergantung pada temperatur dan jenis bahan bakar.

Beberapa masalah yang berhubungan pembakaran biobriket sabut kelapa dengan batubara antara lain : 
a. Kadar air

Kandungan air yang tinggi menyulitkan penyalaan dan mengurangi temperatur pembakaran

b. Kadar kalori

Dari pengujian diketahui bahwa sabut kelapa mempunyai kalori yang jauh lebih rendah jika dibandingkan dengan batubara.

c. Kadar abu

Sabut kelapa mempunyai kadar abu yang rendah, bila dibandingkan dengan batubara.

d. Volatile matter atau zat-zat yang mudah menguap

Kandungan volatile matter pada sabut kelapa lebih tinggi dibanding batubara. Hal ini menyebabkan sabut kelapa lebih mudah terbakar dan menyala.

\section{Bahan perekat}

Perekat adalah bahan yang dapat merekatkan dua buah benda berdasarkan ikatan permukaan. Menurut Brown,et al (2000) dalam (Maarif, 2004) kekutan perekatan dipengaruhi oleh faktor sifat perekatnya sendiri dan tingkat penyesuaian antara jenis bahan perkat dengan bahan yang direkat.

a. Pati Kanji

Menurut Prayitno (1995) dalam (Maarif 2004) penggunaan perekat pati memiliki beberapa keuntungan, antara lain : harga murah, mudah pemakaiannya, dapat menghasilkan kekuatan rekat kering yang tinggi. Namun perekat ini memiliki kelemahan, seperti : ketahanan terhadap air rendah, mudah diserang jamur, bakteri dan binatang pemakan pati. Penelitian yang telah dilakukan Hartoyo dkk, (1978) dalam (Maarif, 2004) menyebutkan bahwa prosedur pembuatan perekat pati dan air adalah dengan menggunakan perbandingan 1 bagian berat tepung pati dan 16 bagian berat air.

b. Tetes tebu (molasses)

Tetes tebu (molasses) adalah hasil samping yang diperoleh dari tahap pemisahan kristal gula. Hasil samping ini cukup berpotensi karena masih mengandung gula sekitar 50 $\%$ - $60 \%$ selain sejumlah asam amino.

\section{METODE PENELITIAN}

Untuk memudahkan jalannya penelitian, maka dibuat flowchart penelitian dapat dilihat pada gambar1 sebagai berikut:

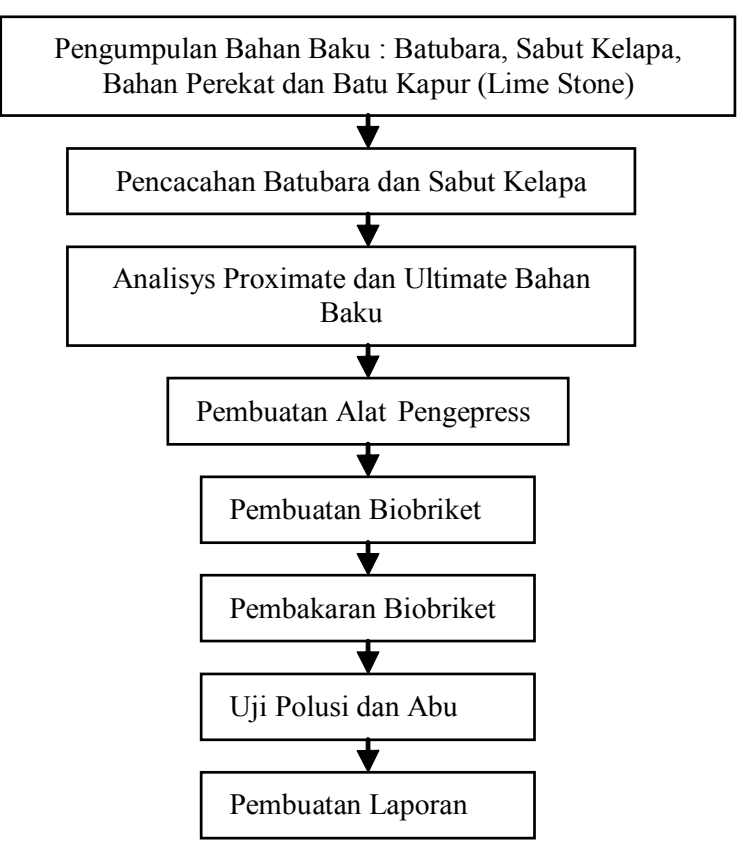

Gambar 1. Flowchart Penelitian

\section{Bahan Baku}

1. Pengumpulan bahan baku

Adapun bahan-bahan yang digunakan dalam penelitian ini adalah:

- Batubara kualitas rendah (lignite) yang masih asli dan belum mengalami proses pengolahan.

- Sabut kelapa, yang diperoleh dari area pertanian di Surakarta dan sekitarnya.

- Bahan perekat biobriket yaiti tepung kanji dan tetes tebu (molasses).

- Batu kapur (limestone) sebagai bahan pengikat polutan

- Gas LPG, sebagai bahan bakar untuk memanaskan tungku pada proses pembakaran biobriket.

2. Pengolahan Bahan Baku

a. Penghalusan batubara menjadi serbuk

b. Pencacahan sabut kelapa menjadi serbuk

c. Pembuatan bahan perekat 


\section{Ultimate Dan Proximate Analysis Bahan Baku}

Setelah bahan baku yang berupa batu bara dan sabut kelapa dihaluskan kemudian dilakukan pengujian utimate dan proximate di UGM.

1. Analisis Proximate

Analisis proximate meliputi; kadar air (M), kadar zat menguap (VM), kadar abu (A), fixed carbon (FC) dan nilai kalor (E). Untuk pengujian nilai kalor dilakukan di Pusat Studi Pangan dan Gizi PAU UGM, sedangkan untuk pengujian kadar air, kadar abu, volatile matter dan fixed carbon dilakukan di Laboratorium Energi Kayu Fakultas Kehutanan UGM.

2. Analisis Ultimate

Analisis ini memberikan informasi analitik yang lebih lengkap dari pada analisi proximate. Hasil analisis ultimate biasa digunakan untuk membandingkan dan menghubungkan sifat-sifat dari batubara disamping itu hasil analisis ini juga dapat digunakan untuk memperkirakan nilai panas batubara dengan menggunakan rumus Dulong. Analisis ini dijalankan dengan analisis kimia untuk menentukan kadar karbon $(\mathrm{C})$, hydrogen $\left(\mathrm{H}_{2}\right)$, oksigen $\left(\mathrm{O}_{2}\right)$, nitrogen $\left(\mathrm{N}_{2}\right)$, belerang, dan abu (A).

\section{Peralatan yang Digunakan}

Peralatan utama yang digunakan dalam penelitian ini terdapat di Laboratorium Teknik Mesin Universitas Muhammadiyah Surakarta dapat dilihat gambar 2 :

1. Alat Pengepresan biobriket Alat pengepres biobriket gambar 3 dibuat deangan cara memodifikasi dongkrak hidraulik yang bertekanan maximal 2 ton

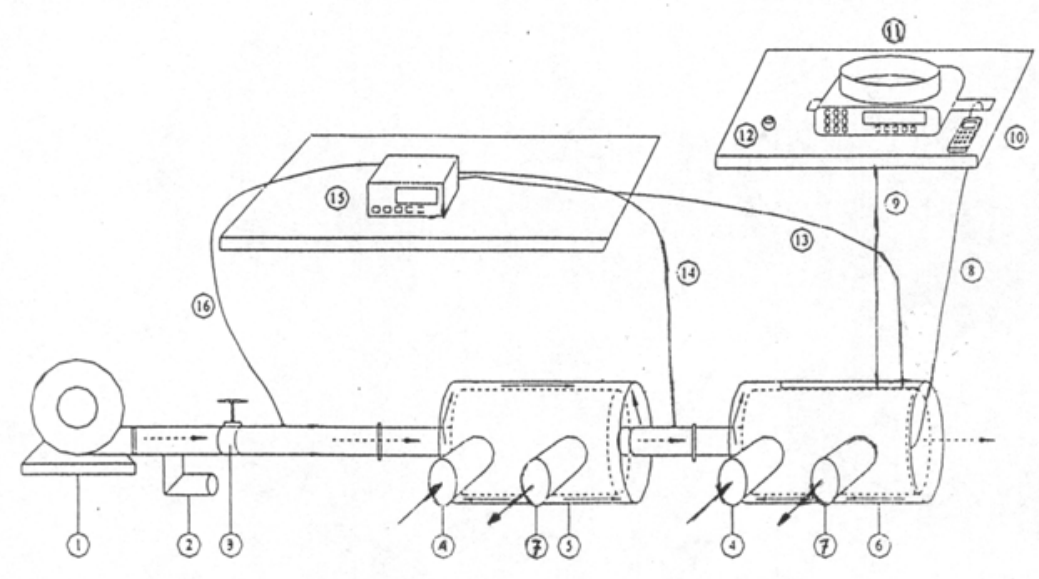

Gambar 2. Sketsa Alat Uji

Keterangan :

$\rightarrow$ Aliran pemanas LPG

- Aliran udara

1. Blower

2. Saluran by pass

3. Katup pengatur aliran udara

4. Saluran masuk pemanas LPG

5. Tungku 1

6. Tungku 2

7. Saluran buang pemanas LPG
8. Termakopel temperatur dinding

9. Kawat penggantung sampel bahan bakar

10. Digital thermocouple reader

11. Electronic professional scale

12. Stop wacth

13. Termokopel temperatur gas pembakaran

14. Termokopel temperatur udara pre-heater

15. Digital thermocouple reader

16. Termokopel temperatur udara supply 
dengan diameter $22 \mathrm{~mm}$ dan dipasang manometer pada saluran pembuangan udara dongkrak yang berfungsi untuk mengukur tekanan pada saat pengepresan.

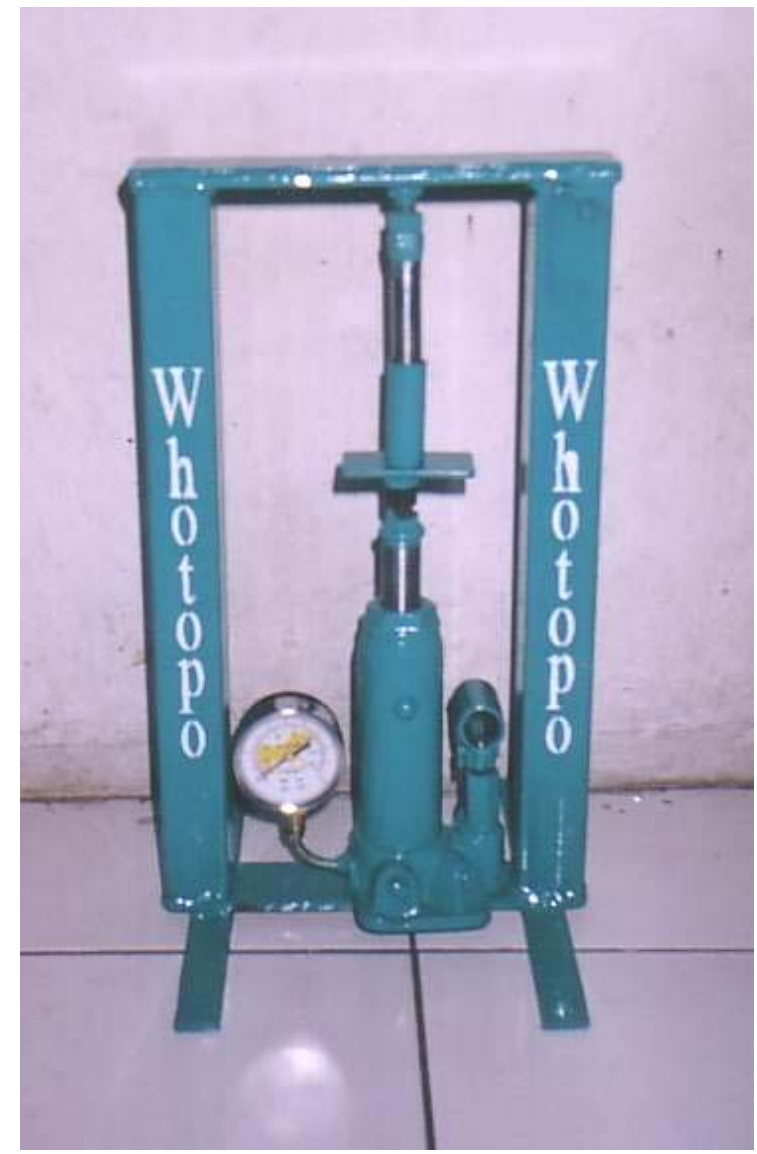

Gambar 3. Alat pengepress Biobriket

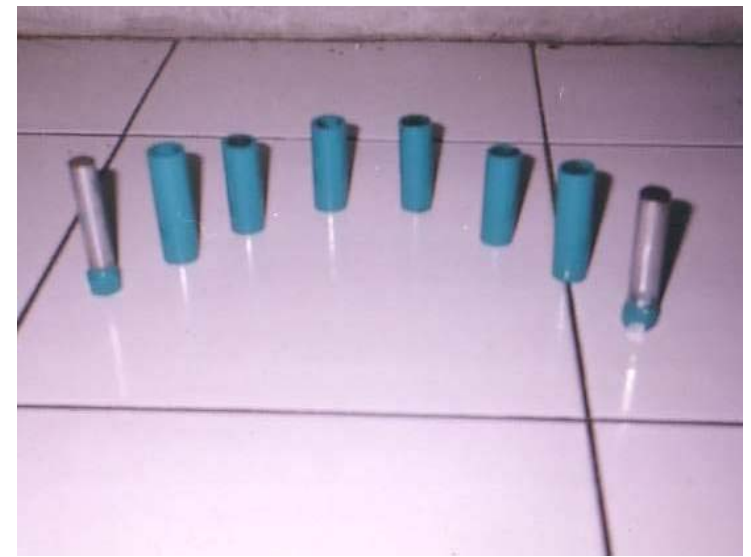

Gambar 4. Alat Pencetak Batubara

\section{Pembuatan Briket}

1. Pencampuran bahan baku

Batu bara, sabut kelapa, bahan perekat dan zat pengikat polutan dicampur hingga rata dengan komposisi sebagai berikut :

a. Sabut kalapa dan batu bara $(70 \%$ : $30 \%$ ) + pati kanji 1 gram

b. Sabut kalapa dan batu bara $(70 \%$ : $30 \%$ ) + pati kanji 2 gram

c. Sabut kalapa dan batu bara $(70 \%$ : $30 \%$ ) + pati kanji 3 gram

d. Sabut kalapa dan batu bara $(70 \%$ : $30 \%$ ) + tetes tebu 1 gram

e. Sabut kalapa dan batu bara $(70 \%$ : $30 \%$ ) + tetes tebu 2 gram

f. Sabut kalapa dan batu bara $(70 \%$ : $30 \%)+$ tetes tebu 3 gram

2. Pencetakan biobriket

Bahan baku yang telah tercampur rata dimasukkan ke dalam cetakan gambar 4 , yang berbentuk silinder dengan diameter 1,5 cm dan tinggi $1,75 \mathrm{~cm}$.

3. Pengepresan

Setelah bahan baku dimasukkan ke dalam cetakan, kemudian dilakukan pengepresan dengan tekanan $100 \mathrm{~kg} / \mathrm{cm}^{2}$ dan didiamkan selama 10 menit. Setelah itu biobriket dikeluarkan dari cetakan dan dikeringkan di tempat yang tidak terkena sinar matahari secara langsung selama 3 hari. Hasil dari spsimen biobriket dapat dilihat pada gambar 5 di bawah :

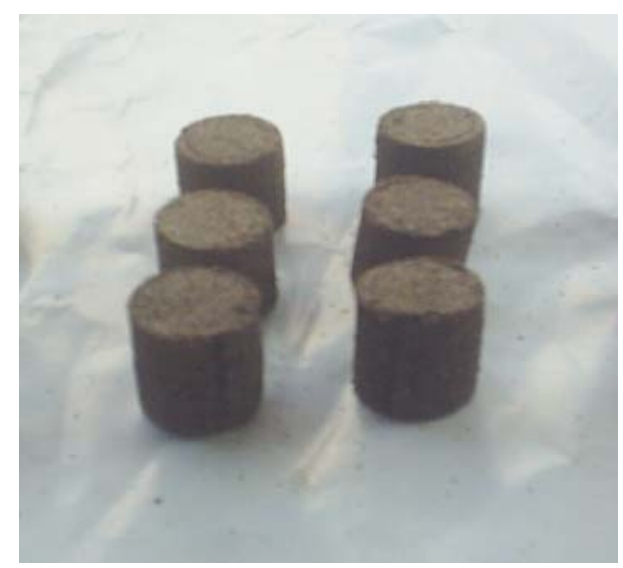

Gambar 5 Spesimen Biobriket 
HASIL PENELITIAN

\section{Sifat-sifat Bahan Dasar}

Dari hasil uji proximate dan ultimate dapat diketahui sifat-sifat bahan dasar seperti yang terlihat pada table 1 sebagai berikut:

\section{Tabel 1. Sifat-sifat Bahan Dasar}

\begin{tabular}{|l|c|c|}
\hline \multicolumn{1}{|c|}{ Sifat } & $\begin{array}{c}\text { Batubara } \\
\text { Lignite }\end{array}$ & $\begin{array}{c}\text { Sabut } \\
\text { Kelapa }\end{array}$ \\
\hline Kadar air (\%) & 14,31 & 2,45 \\
\hline Kadar abu (\%) & 2,02 & 1,34 \\
\hline Fixed Carbon (\%) & 69,53 & 21,62 \\
\hline Nilai kalor (kal/kg) & 5289,395 & 3942,751 \\
\hline Volatile metter (\%) & 14,14 & 74,59 \\
\hline
\end{tabular}

Dari tabel 1 diatas dapat kita lihat bahwa nilai kalor yang dimiliki sabut kelapa masih cukup besar sehingga layak untuk pembuatan briket

\section{Pengaruh Bahan Perekat terhadap Laju Pembakaran}

Variasi bahan perekat mempunyai pengaruh yang signifikan terhadap laju pembakaran. Dalam gambar 6 sampai 9 di bawah, akan disajikan pengaruh variasi bahan perekat terhadap laju pembakaran :

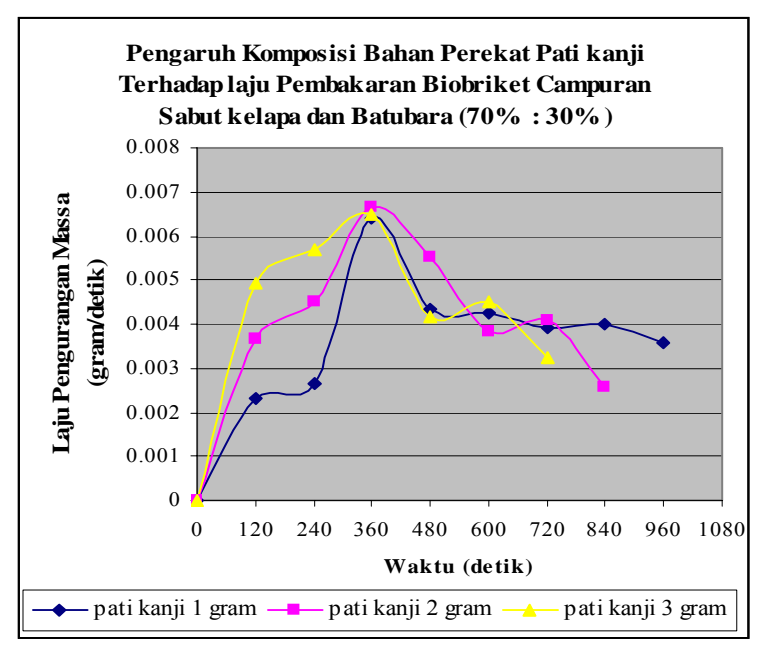

Gambar 6. Grafik pengaruh komposisi perekat patikanji (1 gram, 2 gram dan 3 gram) terhadap laju pengurangan massa biobriket campuran sabut kelapa dan batubara $70 \%: 30 \%$

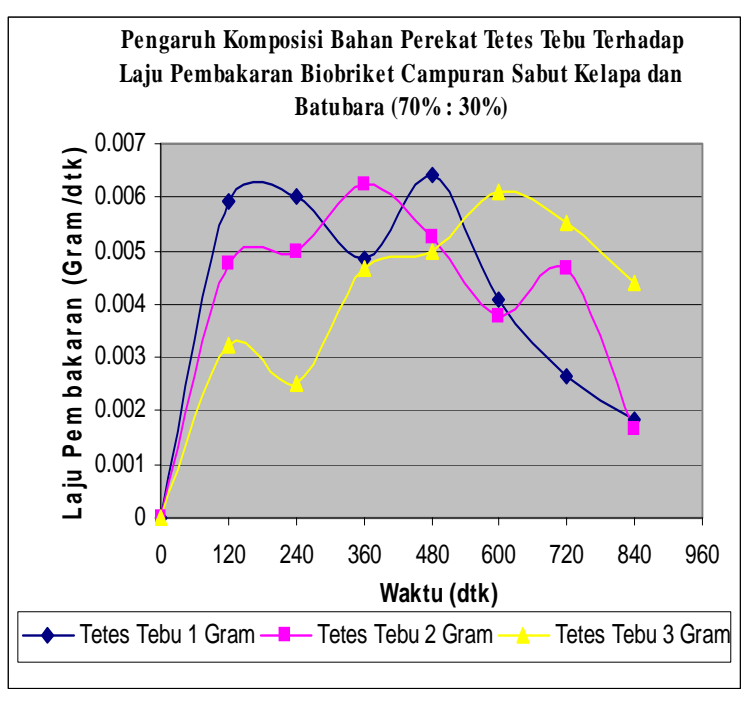

Gambar 7. Grafik pengaruh komposisi perekat tetes tebu (1 gram, 2 gram dan 3 gram) terhadap laju pengurangan massa biobriket campuran sabut kelapa dan batubara $70 \%$ : $30 \%$

Dari gambar 6 dan 7 hasil penelitian diatas, dapat dilihat bahwa Laju pembakaran biobriket dengan perekat pati pada awalnya naik sampai mencapai optimum, sedangkan pada biobriket yang bahan perekatnya tetes tebu pada awalnya juga naik tapi pada saat titik tertentu sebelum mencapi optimum, laju pembakaran akan turun. Hal ini disebabkan karena volatile matter yang dimiliki pati kanji masih cukup tinggi jika dibandingkan dengan tetes tebu.

Pada biobriket dengan perekat pati kanji, semakin banyak campuran pati kanji maka kemungkinan terbakarnya semakin cepat karena nilai volatile matter yang semakin tinggi tetapi yang lebih menarik disini laju pembakan dicapai pada waktu yang sama.

Dari gambar 8 dan 9 diatas dapat dilihat bahwa temperatur yang dihasilkan pada pembakaran biobriket yang berbahan perekat pati kanji lebih tinggi dibandingkan dengan biobriket yang berbahan perekat tetes tebu, ini menunjukkan bahwa perekat pati mempunyai nilai kalor yang lebih tinggi dibandingkan dengan tetes tebu. 


\section{DAFTAR PUSTAKA}

Himawanto, D. A., 2003, Pengolahan limbah pertanian menjadi biobriket sebagai salah satu bahan bakar alternatif, Laporan Penelitian, UNS. Surakarta.

Naruse, I.,Gani, A., Morishita, K., 2001, Fundamental Characteristic on Co-Combustion of Low Rank Coal with Biomass, Proceedings of Riset, Pittsburg.

Sudradjat, 2000, The Potensial of Biomass Energy Resources in Indonesia for the Possible Development of Clean Technology Process (CPT), Laporan Penelitian, Jakarta.

Maarif, S., 2004, Pengaruh Penambahan Arang Tempurung Kelapa dan Penggunaan Perekat terhadap Sifat-Sifat Fisika dan Kimia Briket Arang dari Arang serbuk Kayu Sengon”, Universitas Gadjah Mada, Yogyakarta. 